\title{
A RAIL CAPACITY FRAMEWORK: MAKING THE CASE FOR RAIL FREIGHT EVALUATION IN INDONESIA
}

\author{
Clare Woroniuk, Paulus T. Aditjandra* \\ NewRail - Newcastle Centre for Railway Research, School of Mechanical and Systems Engineering, \\ Newcastle University, Newcastle upon Tyne, NE1 7RU, United Kingdom
}

(Received: December 2014 / Revised: January 2015 / Accepted: March 2015)

\begin{abstract}
Rail is being promoted to play an increasing role in reducing the external cost of freight transportation globally. This is especially the case for nations with high economic growth, such as Indonesia, which require a reliable and efficient transportation system to support global logistics. Ironically, rail freight services in Indonesia have been in decline for more than a decade due to a number of factors including the prioritization of passenger services and strong competition from the road sector. This paper aims to provide a platform for empirical research contextualizing a rail capacity framework, to be applied to the Indonesian system, with a focus on freight services. A desktop review of methodologies employed for capacity evaluation was carried out, in order to identify the most suitable approach for Indonesia. The application of these methodologies will assist in determining current capacity - utilized and unutilized - the results from which can be exercised in future strategic planning.
\end{abstract}

Keywords: Rail freight, Capacity evaluation methods, Indonesia

\section{INTRODUCTION}

Indonesian rail developed with the aim to optimise freight operations between inland farming producers in Java and the ports, in order to allow Indonesian produce to enter the international market. Up until 1939, the railway network was expanding - to 6,797 track km however rail services in Indonesia, in particular freight services, have been in decline now for more than a decade (Kawaguchi et al. 2010). This is as a result of numerous factors, including the prioritisation of passenger services, ageing rolling stock, strong competition from the road sector and the Asian monetary crisis in 1997 (Wachi et al. 2011). Additionally, the issue of safety, the government treatment of the rail industry as the state cash-cow, and human behavior factors further deepened the rail sector's problems in Indonesia (Susantono 2009).

Recent statistics report a meagre rail mode share in Indonesia of $7 \%$ for passenger (200 million passengers per year) and $0.6 \%$ for freight (20 million tonnes of cargo) (Meyrick 2012 b), while road dominates the transport network, with $84 \%$ passenger and $91 \%$ freight (Ministry of Transport, 2007 as cited in Muthohar et al. 2010). By comparison, maritime shipping has a lower modal share than road and rail (Meyrick 2012a). It is acknowledged that shipping will play a prominent role in future development, due to the archipelagic nature of the country, but currently a number of issues are preventing shipping development;

\footnotetext{
*Corresponding author. E-mail: paulus.aditjandra@ncl.ac.uk
} 
limited port capacity, high port access costs, unreliable port performance and unreliability of domestic shipping services (Meyrick 2012a).

In many cases the road network is considered to have a more strategic role than other modes (Lubis \& Sjafruddin 2005), as a result of the rapid development benefits that road expansion brings. The impact of competition from road on rail is demonstrated through railway line closures, across the four regional operations; Java, South Sumatra, North Sumatra and West Sumatra, where 2,539 track km have been closed following a loss of market share to road, leaving only 4,258 track $\mathrm{km}$ in operation.

Recent research in developed countries demonstrates the negative impacts of extensive road development including congestion, pollution, noise and extensive nonrenewable resource reliance (see for example: Banister 2005; Newman \& Kenworthy 1999). Furthermore, road freight in Java has been reported to cause increased maintenance cost as a result of overloading resulting in damage to infrastructure. (Kawaguchi et al. 2010). Commodities such as sand, cement and chemical products (i.e. bulky goods) have the potential to be transported by rail, at greater economy of scale while addressing the green logistics agenda.

In order to accelerate Indonesian economic development, the strategic economic corridor approach MP3EI master plan (Coordinating Ministry for Economic Affairs Republic of Indonesia 2011) has been adopted by the Indonesian government. MP3EI is a holistic approach to the planning process that embraces cross sector integration and coordination of infrastructure and regional development (Susantono 2012). Rail modal shift to achieve green logistics is one of the approaches promoted, which has been adopted in response to the commitment of the signed Kyoto Protocol agreement to reduce greenhouse gas emissions in the long term.

Along with activities involving the realisation of economic development through the strategic corridors, there are, priority projects to promote rail modal shift. These include: on Sumatra an increase in rail capacity to support the palm oil industry. In addition, rail construction is planned to support the coal and steel industries. Rail construction is also planned on Kalimantan to transport coal. To achieve this, from 2011-2015 the government aims to improve the role of trains to handle long distance cargo transport in Java and Sumatra. Following this, from 2016-2020, it is anticipated that a trans- Java, trans- Sumatra railway will be developed, to connect production centres and transport nodes. Leading on from this, by 2021- 2025 it is expected that rail will carry out effective operations as the main alternative to road freight (Centre for Logistics and Supply Chain Studies ITB et al. 2013). It is anticipated that transporting freight by rail can lead to an increase in network capacity, alongside a decrease in negative impacts caused by the dominance of road freight; congestion and infrastructure damage. This has potential benefits for Infrastructure Managers, suppliers and passengers.

In line with the aims of the MP3EI corridor approach and National Railway Master Plan, to accelerate Indonesian railway development, this study aims to provide a platform for empirical research, through contextualizing a rail capacity framework, to be applied to the Indonesian system, with a focus on freight services. This is significant as developing an understanding of current capacity, utilized and unutilized can input to future strategic planning. Unutilised capacity has the potential to accommodate commodities as part of modal shift to rail. Alongside this, an understanding of utilised capacity will provide an opportunity to assess whether rail infrastructure is being optimised currently. This will be achieved through a desktop review of methodologies employed for capacity evaluation, in order to identify the most suitable approach. 


\section{METHODOLOGY}

For this research, a desktop methodology has been employed to review previous studies and identify a suitable methodological approach for capacity evaluation in Indonesia. The literature selection process was conducted through the use of library databases including web of knowledge and Scopus. Following literature identification, the literature under review has been split into two streams: approaches to analyzing railway capacity, and evaluation methods for rail capacity, the latter of which was subdivided further into three: analytical, simulation and optimization methods. Next we discuss rail freight in Indonesia, the market, the policy and the challenges.

\section{INDONESIAN RAIL FREIGHT}

The Indonesian transportation sector is undergoing the preliminary stages of migration, from a state-monopolised economy to an open market for industrial services. Indonesia is projected to become an economically advanced country in 2025 and national economic mobility cannot depend on the highway network alone. A hypothetical study on multimodal transportation networks in Indonesia demonstrated that railway network development will reduce the inland transportation cost and induce some benefit to the interisland transportation network (Sjafruddin et al. 2010). For the rail transportation sector, the Indonesian Railway Company (PT Kereta Api Indonesia) has four main businesses, namely: passenger and freight services in Java islands; coal freight in South Sumatera; and passenger service in Greater Jakarta (including Jakarta, Bogor, Tangerang and Bekasi - JABOTABEK) (Van der Ven 2009). Recent observation shows increasing performance of the Indonesian Railway Company in various aspects, mainly for passenger services including the introduction of an advanced ticketing system, safety record, station revitalisation and landuse (Djuraid 2013). Although rail development in Indonesia can be viewed as having a positive impact, there are governance and financial issues which need addressing (Muthohar \& Sumi 2010).

The National Railway Master Plan (NRMP), a governmental document outlining policies, strategies and a detailed and scheduled programme for the revitalization of the railways for the next 20 years, was mandated in 2007 to address the projection of passenger and freight movement, based on origin and destination of travel. Currently, rail operation in Indonesia serves only 2 main islands: Java - mainly passenger trip - and Sumatra - mainly freight - as reported by Lubis \& Nurullah (2007) and demonstrated in Table 1. There is no existing rail system on the other main islands although plans were reported (see for example Railway Gazette 2012; Railway Gazette 2013).

Table 1. Rail system in Indonesia and its use

\begin{tabular}{lcccc}
\hline & Java & $\begin{array}{c}\text { South } \\
\text { Sumatera }\end{array}$ & $\begin{array}{c}\text { West } \\
\text { Sumatera }\end{array}$ & $\begin{array}{c}\text { North } \\
\text { Sumatera }\end{array}$ \\
\hline Route $(\mathrm{km})$ & 2,944 & 649 & 202 & 463 \\
Traffic 2005 (millions) & 1,454 & 3,650 & 0.036 & 0.498 \\
$\begin{array}{l}\text { Freight } \\
\text { Traffic density / route kms } \\
\text { (thousand) }\end{array}$ & $6 \%$ & $90 \%$ & $100 \%$ & $29 \%$ \\
\hline
\end{tabular}

Source: adapted from Lubis \& Nurullah (2007)

Out of the $6,797 \mathrm{~km}$ of the total railway network in Indonesia, only 3,327 km are integrated as a network and these $3,327 \mathrm{~km}$ are all on the Island of Java. The remaining networks are separated in three regions on the Island of Sumatra. Only 4,258 km of the track 
is operational. In terms of axle load, the Indonesian railway network remains a low standard: only 9-18 tonnes, with relatively low size and a rail weight between $33 \mathrm{~kg} / \mathrm{m}$ (R33) to $54 \mathrm{~kg} / \mathrm{m}$ (R54). Both of these load characteristics - rail strength and carrying capacity - limit the capability of Indonesia's railway network.

The current rail freight market in Indonesia is small as distances from extraction or production to storage are about $250-300 \mathrm{~km}$; secondly, total freight load is limited by low axle load capacity (Dikun 2010). 19 million tonnes of goods lifted in 2008 were delivered by rail freight in Sumatra and Java, and a similar figure in 2009, totalling trips of circa 5,500 million tonnes-km. $80 \%$ of rail freight goods lifted are on Sumatra, with over 15 million tonnes of goods. There has been an increase in rail freight use in Sumatra since 2007 with goods such as fertilisers, palm oil, cement and container all transported by rail at greater economies of scale than other modes. In Java, the rail freight figure is lower, despite a better-integrated system, due to high passenger dominance of capacity, passenger services constitute $95 \%$ of services on Java Island.

\section{REVIEW OF RAILWAY CAPACITY LITERATURE}

This paper aims to contextualize a rail capacity framework, to be applied in Indonesia, which will be situated at the management level.

\subsection{Approaches to Analyzing Railway Capacity}

Railway capacity has been extensively researched and a large number of methods for capacity evaluation have been presented (Burdett \& Kozan 2006; Petersen 1974; Kraft 1982). Railway capacity is a complex term, influenced by several factors; infrastructure, traffic, railway layout and operating parameters. As a consequence there is no recognised definition. In its simplest form rail capacity can be defined as, "the total number of standard train paths that can be accommodated across a critical section in a given time period" (Burdett \& Kozan 2006). However, for the purpose of our research, rail capacity will be understood as: "a measure of the ability to move a specific amount of traffic over a defined rail line with a given set of resources under a specific service plan" (Krueger 1999).

\subsection{Evaluation Methods for Rail Capacity}

Three approaches to evaluate rail capacity have been identified, due to their prevalence in the literature: analytical, simulation and optimisation methods. Analytical methods employ mathematical formulae and algebraic equations to obtain simple models. As a result they are usually employed as a preliminary method of evaluation, but can also be used to validate and calibrate optimisation or simulation models. Simulation models are employed to obtain an in depth replication of railway systems, during a given time period. Optimisation models build on the analytical approach and aim to optimise the timetable. There were few studies addressing rail freight in Indonesia (e.g. Muthohar \& Sumi 2010; Lubis \& Nurullah 2007; Sjafruddin et al. 2010) but none focus on rail freight capacity.

\subsubsection{Analytical Methods}

The state of the art indicates that a number of analytical approaches have been employed in the study of rail networks, yards and lines. An analytical approach is provided by (Huisman et al. 2002) who aimed to develop a solvable queuing network model that computes measures of interest without train schedules. This research divides the railway network into components. It is argued that, through the provision of a clear definition of each component, the railway network is transformed into a product from a queuing network. 
The formation of a product from a queuing network justifies the decomposition of the network and its components, which in turn justifies a more detailed analysis of each component in isolation. To obtain this, some simplifying and modifying assumptions have to be made. The presented model employs $\mathrm{M} / \mathrm{M} / \mathrm{m}$ queues meaning that closed form expressions for mean delays are obtained. The model is capable of evaluating network designs, traffic scenarios and capacity expansions (Huisman et al. 2002). This model has been implemented successfully to analyse both the existing network and to investigate potential bottlenecks in new railway designs in Holland. In 2005, an attempt to standardise the approach to capacity evaluation was presented by UIC (International Union of Railways).

In 2006, Burdett \& Kozan applied an analytical approach, to calculate theoretical capacity, wherein both static and dynamic railway resources are considered. Capacity is calculated using train proportions, signal location and dwell time, providing an average section running time; as a result, the lower and upper bounds of capacity for the route under analysis, can be determined. It is anticipated that this approach can be applied to both railways where passenger traffic is dominant such as in the EU, together with long distance freight networks as seen in the US and Australia.

Lai et al (2010) discuss an analytical capacity model which calculates hourly train and passenger throughput, while considering mixed traffic and complex track layouts. Taiwan Railways Administration implemented this model, during capacity assessment. Lai \& Wang (2012) provide a review of the Taiwan Railways Administration's capacity model and further develop the idea to include new capacity models for rail networks with advanced signalling systems. They identify that track layout and track usage at stations, also influences capacity and along with advanced signalling, highlight track laying and a signalling system upgrade as factors which can increase capacity.

\subsubsection{Simulation Methods}

The literature suggests that simulation modelling is used more frequently in capacity analysis, due to its ability to provide a detailed replication of operations (Marinov \& Viegas 2011). Dessouky \& Leachman (1995) identify a methodology for the study of complex rail networks. This approach considers the challenges of modelling networks, using an analytical methodology, and presents an approach for single and double track. This approach has been employed to analyse an example from the USA examining the network between the mainline in Los Angeles and the ports at Long Beach. Simulation modelling of the case has lead to several alternative scenarios for rail development being produced. Marinov \& Viegas (2011) identify a mesoscopic simulation modelling methodology, to capture the impact of freight operations in a network, through the analysis of individual network components. This method has been employed by a rail freight operator in Portugal, as they move to practice schedule operations. A strict fixed schedule carries the risks of low resource utilization and operating efficiency, however it is anticipated that simulation modelling, prior to operation can help to address these.

\subsubsection{Optimisation Methods}

A number of advances in optimization methods are demonstrated in the literature. Assad (1980) identifies analytical optimising network models that aim to reveal the optimal route through a network, while incorporating additional costs, such as delays. Crainic \& Laporte (1997) present optimising models wherein the network is presented in graphical form, with a number of arcs and nodes. The links between the transport facilities are represented by arcs and the transport facilities are represented by nodes. The arcs and nodes 
represent physical capacity and processing capability. As a result, the processing capability of the network is graphically depicted.

In summary, the methodological approach is often dependent on the specific case or network. Analytical methods provide a viable option for preliminary analysis; however a disadvantage of this approach may be model sensitivity to parameter input. For more in depth analysis, simulation and optimisation methods, or a combination of both, may be employed.

\section{DISCUSSION}

To contribute towards Indonesian rail development, a rail capacity framework is proposed, in order to identify the current capacity status. At present, Indonesian railways are not deemed to hold a positive correlation to the national economy, due to issues including state monopoly, passenger transport subsidy, and lack of investment to maintain and update infrastructure (Dikun 2010; Susantono 2013). In line with the MP3EI strategic corridor approach, it is anticipated that future Indonesian rail development will be linked to an increase in demand for passenger and freight services, which will occur as a result of economic growth and its redistribution. The expected increase in rail freight market share is $5-10 \%$ by 2020 from current levels of $3 \%$ (please note that the figure on $0.6 \%$ in the introduction is the rail share of all freight, including small local road movements for which rail is not a feasible option) (Meyrick 2012b).

Knowledge of current freight operations in Indonesia must first be considered. These include a network that is not fully interlinked, except on Java Island; transport distances of between 250-300km; and a relatively low axle load of 9-18 tonnes. At present, rail freight mostly transports bulk commodities; palm oil, coal, cement and a small number of containers from inland farming areas to the ports. Having discussed both the current operations and the methodological approaches presented within the state of the art, we propose that the most suitable approach would be a combination of analytical and simulation approaches. We recommend this option for Indonesia, as previous research has indicated that the application of these two approaches concurrently can lead to a more robust set of results. In addition, an optimisation approach has not been put forward at this time, as the research aims to provide a framework to understand the available capacity.

In terms of an analytical approach, the model presented by Huisman et al (2002) could be applied, as it has been used to analyse both capacity analysis of the existing network and in the examination of bottlenecks in new rail line designs, in particular a new freight line providing a link to a port which is relevant Indonesia as rail freight is currently used to access the ports. By comparison, the capacity evaluation model developed by Lai \& Wang (2012) could be implemented, to assess the advantages of a signal system upgrade in Indonesia. However, we reason that the analytical approach presented by Burdett and Kozan (2006) would be the most suitable for this study, as the lower and upper bounds of capacity could be calculated for each of the routes, examining total capacity for the network and bottlenecks in the system where the infrastructure is under pressure. This information would provide a valuable input into future timetable and operational management planning.

To validate the results of the analytical modelling and to provide a more detailed replication of operations, we suggest the implementation of simulation modelling. The timetable generator stochastic simulation model developed by Yalcinkaya \& Bayhan (2012) may be employed, as it would allow the evaluation of theoretical capacity and determine a realistic timetable for each of these routes. By contrast, the mesoscopic simulation methodology developed by Marinov and Viegas (2010) could be implemented to analyse freight operations, however it is recognized that passenger operations would also need to be considered in order to build a complete picture of network capacity. 
Having taken into account previous studies, we propose that the most suitable simulation approach for Indonesia is the methodology presented by Dessouky and Leachman (1995). This will complement the analytical method suggested and will be suitable for the Indonesian network, as the methodology is insensitive to network size. Previous research has indicated that this method has been applied with success to analyse low capacity single track lines linking to ports, which is similar to development plans for Sumatra to support the palm oil industry. Although the model presented by Yalcinkaya \& Bayhan (2012) would allow the calculation of theoretical capacity it also focuses largely on train scheduling and timetabling, whereas Dessouky \& Leachman (1995) highlights network capacity, the objective of the proposed framework.

In addition, applying simulation modelling will allow for the assessment of a number of potential rail developments such as on Kalimantan, to promote the coal industry and the impact on capacity these may have.

In previous research, overloading of bulk commodities has been identified as a factor in damage to infrastructure by road transport. The evaluation of capacity will identify unutilized capacity on rail which could be utilized by bulk commodities and avoid further damage. Indonesia may refer to neighbouring countries as cases where the transfer of bulk commodities from road to rail has been successfully achieved via freight dedicated corridor or double rail track development. Indonesia may wish to employ additional measures, implemented successfully in India, to increase profit in the railways such as an increase in axle load for bulk commodities and an improvement in wagon utilization have been implemented with a 9\% increase in tonne charge per train (Amos 2009). Measures that Indonesia might employ, which have been successfully undertaken in Malaysia, include a double track and electrification scheme that have lead to an increase in track capacity and infrastructure capability benefits. Nevertheless the applicability of lessons learnt from neighbouring countries should be considered, as these may only be suitable for the larger islands in Indonesia such as Java and Sumatera, as discussed earlier.

\section{CONCLUSION}

This research aimed to provide a platform for novel empirical research, through contextualising a rail capacity framework for Indonesia, with a focus on freight services. To achieve this, a desktop review of methodologies employed for capacity evaluation has been employed, in order to identify the most suitable approach Table 2. demonstrates the recommended rail freight capacity evaluation framework for Indonesia.

It is envisaged that the application of these methodologies will assist in determining current capacity- utilised and unutilised - the results from which can be exercised in future strategic planning. In addition, the link between rail freight and the multimodal integrated logistics approach, that was developed to address the islands characteristics of Indonesia, could also be opened for further investigation.

Table 2. Capacity evaluation framework for Indonesia

\begin{tabular}{lll}
\hline $\begin{array}{l}\text { Methodological } \\
\text { Approach }\end{array}$ & Suitability for application in Indonesia & Data Required \\
\hline Analytical & $\bullet$ This approach is most suitable for application, as & $\bullet$ Route timetable \\
methodology - & the lower and upper bounds of capacity could be & $\bullet$ Map \\
(Burdett \& & calculated for each route in the network. & $\bullet$ Service \\
Kozan 2006) & $\begin{array}{l}\text { Applying this methodology will allow the } \\
\text { examination of total capacity for the network both }\end{array}$ & $\begin{array}{c}\text { structure, } \\
\text { Route operating } \\
\end{array}$ \\
& utilised and unutilised. & form \\
\hline
\end{tabular}


Table Continued.

\begin{tabular}{|c|c|c|}
\hline $\begin{array}{l}\text { Methodological } \\
\text { Approach }\end{array}$ & Suitability for application in Indonesia & Data Required \\
\hline $\begin{array}{l}\text { Analytical } \\
\text { methodology - } \\
\text { (Burdett \& } \\
\text { Kozan 2006) }\end{array}$ & $\begin{array}{l}\text { - It will also be possible to identify bottlenecks in the } \\
\text { system where the infrastructure is under pressure } \\
\text { which can input into future timetable and } \\
\text { operational management planning. }\end{array}$ & $\begin{array}{l}\text { - Services } \\
\text { including train } \\
\text { specific } \\
\text { information } \\
\text { - Topography }\end{array}$ \\
\hline $\begin{array}{l}\text { Simulation } \\
\text { modelling - } \\
\text { (Dessouky \& } \\
\text { Leachman } \\
\text { 1995) }\end{array}$ & $\begin{array}{l}\text { - Methodology is suitable for the Indonesian network } \\
\text { as it is insensitive to network size. } \\
\text { - This method has been applied previously with } \\
\text { success to analyse low capacity single track lines } \\
\text { providing a link to ports. } \\
\text { - Development plans for Sumatra and Kalimantan } \\
\text { include the provision of port links to support the } \\
\text { coal and palm oil industries. Previous } \\
\text { implementation of this method analysing port links, } \\
\text { indicates that it will be suitable for Indonesia. } \\
\text { - Applying simulation modelling prior to } \\
\text { construction will allow for the assessment of a } \\
\text { number of potential rail developments and an } \\
\text { assessment of the impact on capacity these may } \\
\text { have. }\end{array}$ & $\begin{array}{l}\text { - Total axle load } \\
\text { and payload of } \\
\text { train }\end{array}$ \\
\hline
\end{tabular}

\section{ACKNOWLEDGEMENT}

The generosity of Thomas H Zunder, freight and logistics expert at Newcastle University, in supporting this study is gratefully appreciated. This paper has emerged from an earlier paper presented at the $5^{\text {th }}$ Transport Research Arena (TRA) Conference in June 2014, Paris, France. Since that date it has been revised, having benefited from comments from this conference and reviews on related work.

\section{REFERENCES}

Amos, P., 2009. Freight transport for development toolkit: rail freight, Washington D.C.: World Bank Department for International Development.

Assad, A.A., 1980. Models for rail transportation. Transportation Research Part A: General, 14, pp.205-220.

Banister, D., 2005. Unsustainable Transport City Transport in the new century, Abingdon:

Routledge Taylor \& Francis Group.

Burdett, R.L. \& Kozan, E., 2006. Techniques for absolute capacity determination in railways.

Transportation Research Part B: Methodological, 40, pp.616-632.

Centre for Logistics and Supply Chain Studies ITB et al., 2013. State of Logistics Indonesia 2013, Jakarta.

Coordinating Ministry for Economic Affairs Republic of Indonesia, 2011. Masterplan for Acceleration and Expansion of Indonesia Economic Development 2011-2025 2nd ed., Jakarta: Coordinating Ministry for Economic Affairs, Republic of Indonesia. 
Crainic, T.G. \& Laporte, G., 1997. Planning models for freight transportation. European Journal of Operational Research, 97, pp.409-438.

Dessouky, M.M. \& Leachman, R.C., 1995. A simulation modelling methodology for analyzing large complex rail networks. Simulation, 65(2), pp.131-142.

Dikun, S., 2010. Future Indonesian Railways An Interface Report Towards The National Railway Master Plan, Jakarta. Indonesia Infrastructure Initiative (IndII), Australia Indonesian Partnership.

Djuraid, H.M., 2013. JONAN \& Evolusi Kereta Api Indonesia 3rd ed., Jakarta: Sarana Kata Grafika.

Huisman, T., Boucherie, R.J. \& Van Dijk, N.M., 2002. A solvable queueing network model for railway networks and its validation and applications for the Netherlands. European Journal of Operational Research, 142, pp.30-51.

Kawaguchi, H., Wachi, T. \& Sadayuki, Y., 2010. Freight flow analysis and estimation of pavement cost reduction by overloaded truck utilizing weighbridge survey in the Central Java region. In 12th World Conference on Transport Research Lisbon Portugal. pp. 118.

Kraft, E.R., 1982. Jam capacity of single track rail lines. In Proceedings of the 23rd Annual Meeting Transportation Research Forum. New Orleans: Transportation Research Forum, pp. 461-471.

Krueger, H., 1999. Parametric modeling in rail capacity planning. WSC'99. 1999 Winter Simulation Conference Proceedings. "Simulation - A Bridge to the Future" (Cat. No.99CH37038), 2, pp.1194-1200.

Lai, Y.-C. (Rex), Shih, M.-C. \& Jong, J.-C., 2010. Railway Capacity Model and Decision Support Process for Strategic Capacity Planning. Transportation Research Record: Journal of the Transportation Research Board, 2197(2), pp.19-28.

Lai, Y.-C. \& Wang, S.-H., 2012. Development of Analytical Capacity Models for Conventional Railways with Advanced Signaling Systems. Journal of Transportation Engineering, 138(JULY), pp.961-974.

Lubis, H.A.S. \& Nurullah, P., 2007. Recent development of Indonesian railway institution. Journal of the Eastern Asia Society for Transportation Studies, 7(13), pp.1886-1901.

Lubis, H.A.S. \& Sjafruddin, A., 2005. Multimodal transport in Indonesia: recent profile and strategy development. Journal of the Eastern Asia Society for Transportation Studies, 5 , pp.46-64.

Marinov, M. \& Viegas, J., 2011. A mesoscopic simulation modelling methodology for analyzing and evaluating freight train operations in a rail network. Simulation Modelling Practice and Theory, 19, pp.516-539.

Meyrick, S., 2012a. Multimodal transport strategy: Java corridor final report of scoping study - Consultant Report, Porthcawl Pty Ltd. Australian AID Indonesia Infrastructure Initiative (IndII).

Meyrick, S., 2012b. OECD Reviews of Regulatory Reform INDONESIA Regulatory and Competition Issues in Port, Rail and Shipping, Porthcawl Pty Ltd. OECD.

Muthohar, I. \& Sumi, T., 2010. Sustaining Political and Financial Allocation as a Sustainable Approach in Transport Policy Development: The Case of Indonesia's Railway during the Restructuring Process. Journal of Sustainable Development, 3(3), pp.76-84.

Muthohar, I., Sumi, T. \& Sutomo, H., 2010. The Implementation and Impacts of PSO , IMO, and TAC Schemes on National Railways Reform in Indonesia. Journal of the Eastern Asia Society for Transportation Studies, 8.

Newman, P. \& Kenworthy, J.R., 1999. Sustainability and cities: overcoming automobile dependence, Washington D.C.: Island Press. 
Petersen, E.R., 1974. Over-the-Road Transit Time for a Single Track Railway. Transportation Science, 8, pp.65-74.

Railway Gazette, 2012. PPP model to fund Kalimantan coal network. Available at: http://www.railwaygazette.com/news/single-view/view/ppp-model-to-fund-kalimantancoal-network.html.

Railway Gazette, 2013. Rail network proposed in Sulawesi. Available at: http://www.railwaygazette.com/news/infrastructure/single-view/view/rail-networkproposed-in-sulawesi.html.

Sjafruddin, A. et al., 2010. Policy Evaluation of Multimodal Transportation Network : The Case of Inter-island Freight Transportation in Indonesia. Asian Transport Studies, 1(1), pp.18-32.

Susantono, B., 2009. 1001 Wajah Transportasi Kita A. Endah, ed., Jakarta: PT Gramedia Pustaka Utama.

Susantono, B., 2012. Manajemen Infrastruktur dan Pengembangan Wilayah (Managing Infrastructure and Regional Development), UI-Press.

Susantono, B., 2013. Transportasi \& Investasi, Jakarta: Penerbit Buku KOMPAS.

Van der Ven, J., 2009. The market for railways in Indonesia, Jakarta. Indonesia Infrastructure Initiative.

Wachi, T. et al., 2011. Development of Railway Regulatory Scheme in Central Java Region of Indonesia. Transportation Research Record: Journal of the Transportation Research Board, 2239, pp.93-100.

Yalçinkaya, Ö. \& Mirac Bayhan, G., 2012. A feasible timetable generator simulation modelling framework for train scheduling problem. Simulation Modelling Practice and Theory, 20, pp.124-141. 